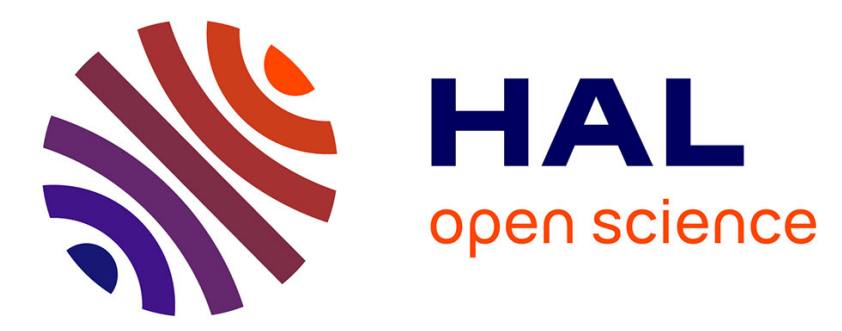

\title{
Antibiotics as physiological stress inducers and bacterial response to the challenge
}

Didier Mazel, Shahriar Mobashery

\section{To cite this version:}

Didier Mazel, Shahriar Mobashery. Antibiotics as physiological stress inducers and bacterial response to the challenge. Current Opinion in Microbiology, 2012, 15 (5), pp.553-554. 10.1016/j.mib.2012.09.002 . pasteur-01699483

\section{HAL Id: pasteur-01699483}

\section{https://hal-pasteur.archives-ouvertes.fr/pasteur-01699483}

Submitted on 2 Feb 2018

HAL is a multi-disciplinary open access archive for the deposit and dissemination of scientific research documents, whether they are published or not. The documents may come from teaching and research institutions in France or abroad, or from public or private research centers.
L'archive ouverte pluridisciplinaire HAL, est destinée au dépôt et à la diffusion de documents scientifiques de niveau recherche, publiés ou non, émanant des établissements d'enseignement et de recherche français ou étrangers, des laboratoires publics ou privés.

\section{(1)(1) $\$(0)$}

Distributed under a Creative Commons Attribution - NonCommercial - ShareAlikel 4.0 


\title{
Editorial Overview: Antimicrobials:
}

\section{Antibiotics as Physiological Stress Inducers and Bacterial Response to the Challenge}

\author{
Didier Mazel $^{1}$ and Shahriar Mobashery ${ }^{2}$ \\ ${ }^{1}$ Institut Pasteur, Unité Plasticité du Génome Bactérien , CNRS UMR3525, Département \\ Génomes et Génétique, 75724 Paris cedex 15, France; ${ }^{2}$ Department of Chemistry \& \\ Biochemistry, University of Notre Dame, Notre Dame, Indiana 46556, USA.
}

Didier Mazel is professor at the Pasteur Institute, Head of the Unité Plasticité du Génome Bactérien and director of the department "Genomes and Genetics". His research group works on gene capture, horizontal gene-transfer mechanisms, and Vibrio genomics, with a particular focus on integrons.

Shahriar Mobashery holds the Navari Chair in the Department of Chemistry and Biochemistry at the University of Notre Dame. He leads a multidisciplinary group of scientists. His research interests span studies of the mechanisms of antibiotic resistance, design of new classes of antibiotics and investigations of bacterial cell wall.

The rise of antibiotic resistance and its dissemination among Gram-negative and Grampositive bacteria present challenges to treatment of infections. As the need for new antibacterials is presently great, it is essential to understand what led to this inexorable selection over the past 50 years. This knowledge will guide us in arriving at policies to address the clinical problem and to define strategies to reverse the disconcerting trend [1]. Whereas the scope of the problem is daunting and the options for remedies limited, in this issue of Current Opinions in Microbiology we have seven articles that discuss the state of the art in knowledge on several important facets of this incredibly complex and yet important scientific challenge.

Significant knowledge is in hand on transposable elements, plasmids and other mobile genetic elements, and on their synergic interactions for the capture and dissemination of resistance determinants. However recent studies have revealed that selection for resistance could be more complex than previously thought. The review by Hughes and Andersson analyzes the difference between the selection of resistance phenotypes and the evolution of bacteria, when confronted with either lethal concentrations of drugs or with the more frequent non-lethal concentrations encountered in the environment. They 
present evidence that mutations are rapidly enriched, and selected de novo, at very low antibiotic concentrations and discuss how this can contribute to the stepwise development of antibiotic resistance.

Another important issue is the role played by antibiotics as triggers of genetic diversification. The review by Blázquez and colleagues examine another facet of the effect of sub-lethal concentrations of antibacterials: their role as promoters of genetic variation. The authors argue that antibiotics, especially when present at non-lethal concentrations, are responsible for increased genetic variation, and therefore, paradoxically participate in the emergence of antibiotic resistance. Antibiotics may cause genetic changes by different pathways. These involve an increase of free radicals inside the cell or oxidative stress that induces the SOS response and its attendant triggering of the error-prone polymerase action. They can also lead to imbalance in nucleotide metabolism or act directly on DNA. In addition, antibiotics have been shown to induce horizontal gene transfer of antibiotics resistance encoding ICEs (Integrative and Conjugative Elements) and gene cassette capture in integron. The authors discuss in detail the relevance of these phenomena within the context of antibiotic-resistance development.

The review by Charpentier, Polard and Claverys debates the role of antibiotics as inducers of competence for genetic transformation, which has recently been observed in the distantly related species Streptococcus pneumoniae and Legionella pneumophila. In particular, they discuss the role that can be played by this competence induction in bacteria that lack the SOS response, and draw a parallel with the SOS induction by antibacterials in other bacteria. They propose that competence is a stress response that can substitute for SOS in bacteria defective for it and discuss it the context of convergent evolution.

The review by Dantas and Sommer deals with a crucial question arising from metagenomic studies and the resistome definition. Recent studies have revealed a wealth of genetic resources in terms of resistance genes in bacteria sharing the same ecological niche. Nonetheless, it is hard to predict which genes will be shared in isolates of remote species that share the niche. This reveals a highly diverse and complex network for genetic exchange among bacteria, especially among pathogens and environmental organisms, where one can identify the identical resistance genes and 
mobile elements. To complicate the situation, in some cases, clinically relevant resistance genes might have been acquired from organisms in which their native function would not be manifestation of antibiotic resistance. In their review, the authors attempt to distinguish the resistance phenotype from the resistome genotype, and explain why this distinction is important to understanding the relevance of environmental niches that contribute most to clinical problems associated with antibiotic resistance.

As mentioned above, acquisition of exogenous genetic material is the main route for the development of resistance to numerous classes of antibacterial drugs in a wide range of pathogenic bacteria. However, characterization of a novel mechanism of resistance to ceftazidime in Burkholderia pseudomallei has revealed that resistance can also occasionally come about by gene loss. This scenario is likely not common, as most antibiotics target essential cellular functions for which there is no functional redundancy. In their review, Török, Chantratita and Peacock narrate the steps of this discovery and discuss what rendered it possible in this specific context.

The review by Mediavilla and colleagues examines the epidemiology of communityassociated methicillin-resistance Staphylococcus aureus (CA-MRSA) strains, which are increasingly implicated in nosocomial infections, and may eventually displace hospitalassociated MRSA strains in hospitals. They review the current molecular epidemiology of the different CA-MRSA sequence types, as defined from MLST, with respect to genetic diversity, global distribution, and factors related to their emergence and spread. They present data showing that distinctions based on clinical epidemiology and susceptibility are becoming less relevant, arguing in favor of genotypic definitions, which would reflect better the continuously emerging "waves" of MRSA evolution.

Finally, the review by Bagnoli and colleagues examine the interplay between vaccines and antibiotics treatments, and the possible role of new vaccines as a promising solution to the rise of antibiotic resistance in most pathogenic bacteria. They present a thoughtful perspective on the different selective forces exerted by vaccines and antibiotics, which impact the manner in which bacteria escape their action. In particular they draw parallels and contrasts in the observation that emergence of antibiotic-resistant pathogens is inexorable, whereas efficacious vaccines have never been shown to elicit vaccine-resistant strains. They also discuss the fact that vaccines are contributing to the reduction of antibiotic usage through the establishment of herd immunity by limiting 
transmission of pathogenic bacteria to potentially susceptible individuals and therefore limiting the numbers of infections in the overall population.

The static view of antibacterials as mere toxic compounds to bacteria that simply bind a target and kill is refuted. The biological response by bacteria to exposure to antibiotics is multifaceted from the physiological point of view and the response in the form of mechanisms of resistance that are selected and disseminate are complex. The reviews in this issue describe other, sometimes unexpected, outcomes to the various effects of sublethal concentrations of antibiotics on bacterial physiology and evolution, in complement to transcriptional activation events reviewed earlier in Current Opinion in Microbiology (2). The understanding of these processes has gained additional poignancy in light of significantly diminished activity in the pharmaceutical industry over the past two decades in discoveries of new drugs for treatment of bacterial infections. Only time will tell, if humanity would keep one step ahead of evolution of antibiotic resistance in bacteria.

References:

1. Bush, K, Courvalin, P, Dantas, G, Davies, J, Eisenstein, B, Huovinen, P, Jacoby, GA, Kishony, R, Kreiswirth, BN, Kutter, E, Lerner, SA, Levy, S, Lewis, K, Lomovskaya, O, Miller, JH, Mobashery, S, Piddock, LJV, Projan, S, Thomas, CM, Tomasz, A, Tulkens, PM, Walsh, TR, Watson, JD, Witkowski, J, Witte, W, Wright, G, Yeh, P, Zgurskaya, HI Tackling Antibiotic Resistance, Nat. Rev. Microbiol. 2011, 9: 894896.

2. Davies J, Spiegelman GB, Yim G. The world of subinhibitory antibiotic concentrations. Curr Opin Microbiol. 2006 9(5):445-453. 